\title{
Preconcentration of Sunset Yellow Dye Using $\beta$-Cyclodextrin Butanediol Diglycidyl Ether Polymer as the Solid Phase Extractant
}

\author{
RUPINDER KAUR ${ }^{*}$ and USHA GUPTA \\ Department of Chemistry, Punjabi University, Patiala, Punjab, India \\ rupimphil@yahoo.com
}

Received 11 September 2013 / Accepted 6 October 2013

\begin{abstract}
A method has been developed for the preconcentration of trace amounts of sunset yellow dye using a newly synthesized $\beta$-cyclodextrin butanediol diglycidyl ether polymer ( $\beta$-CDP). Various parameters such as effect of $\mathrm{pH}$, sample volume, shaking time, agitation time, amount of adsorbent for the \% uptake of the sunset yellow have been optimized. $\beta$-CDP could be used repeatedly and offered a better recovery of sunset yellow. The method has been for the determination of sunset yellow in different food samples.
\end{abstract}

Keywords: $\beta$-Cyclodextrin 1,4-butanediol diglycidyl ether polymer, Sunset yellow dye, Preconcentration, Spectrophotometry

\section{Introduction}

Synthetic dyes are widely used for improving the color and enhancing the visual aesthetic appeal of some foods and this effect is maintained throughout the production process and during storage. They present high stability to light, oxygen and $\mathrm{pH}$ changes and have lower prices compared to natural dyes ${ }^{1,2}$. Sunset yellow dye is widely used as additives in soft drinks and other food samples. The use of synthetic dyes is strictly controlled by laws, regulations and acceptable daily intake (ADI) values. The allowable limit for sunset yellow mainly used in non-alcoholic beverages and the ADI values are 0 and $2.5 \mathrm{mg} \mathrm{kg}^{-1}$. Dye can cause adverse toxicological effects, being considered as unhealthily substances for humans ${ }^{3}$. Analytical techniques such as spectrophotometry ${ }^{4-7}$, column solid-phase extraction ${ }^{8}$, derivative spectrophotometry $^{9}$, HPLC $^{10}$, kinetic determination ${ }^{11}$, second derivative spectrophotometry ${ }^{12}$, adsorptive stripping voltammetric ${ }^{13}$. Some of the above methods are very costly and required the expert hands. So, spectrophotometry is widely used for the determination of dyes due to its higher sensitivity, low cost, low interference level and its excellent detection limits. So, sunset yellow dye has been determined by spectrophotometric methods after preconcentration using $\beta$-CDP in food samples. 
Supramoleculer complexes with $\beta$ - cyclodextrin has been a very active research field in the past few years ${ }^{14-16} . \beta$ - cyclodextrin $(\beta$-CD) is a very stable oligosaccharide that is composed of seven glucose units linked with each other by $\alpha$-(1,4)-glycosidic linkage. It can form supramoleculer complexes with several organic compounds by incorporating them into their hydrophobic cavities. Two or more $\beta$-cyclodextrin covalently linked with each other are known as polymers. These $\beta$-cyclodextrin polymer have been used for the preconcentration of various analytes ${ }^{17-20}$. In the present work, $\beta$-cyclodextrin 1,4-butanediol diglycidyl ether polymer $(\beta$-CDP) has been used as a solid support for the preconcentration of sunset yellow dye.

\section{Experimental}

A Shimadzu UV-1800 spectrophotometer (Shimadzu Ltd., Japan) equipped with the matched $10 \mathrm{~mm}$ quartz cells was used to measure absorbance. Digital century $\mathrm{pH}$-meter $\mathrm{C}_{\mathrm{p}}-901$ with a combined glass electrode was used to carry out $\mathrm{pH}$ measurements. A thermostatic shaking water bath (Perfit India Ltd.) was used to carry out all the inclusive procedures.

\section{Reagents}

All the chemicals used were of Anal R grade unless otherwise stated. Double distilled water was used throughout the experiment. Brilliant green dye solution was prepared by dissolving $0.482 \mathrm{~g}$ in $100 \mathrm{~mL}$ of double distilled water to give $0.01 \mathrm{M}$ standard stock solution and further dilutions were made as when required.

$20 \mathrm{~g}$ of $\beta$-CD was dissolved in $50 \mathrm{~mL}$ of $20 \% \mathrm{NaOH}$. To this $20 \mathrm{~mL}$ of butanedioldiglcidyl ether was added drop wise. The polymer was formed in $1.5 \mathrm{~h}$ and dried at $90{ }^{\circ} \mathrm{C}$ in oven. The polymer was washed with double distilled water 5-6 times. Then, the polymer was dried again at $90{ }^{\circ} \mathrm{C}$ and kept at room temperature in desiccator for further use

Buffer solution in the $\mathrm{pH}$ range of 2.0-3.5 were made by mixing equimolar solutions of hydrochloric acid/sodium acetate and buffer solutions in the $\mathrm{pH}$ range of 4.0-6.5 were made by mixing equimolar solutions of sodium acetate and acetic acid solutions in the different proportions While those in the $\mathrm{pH}$ range of 7.0-11.0 were made by mixing equimolar solutions of ammonia and ammonium chloride. The glass wares were washed with chromic acid and soaked in 5\% nitric acid and then cleaned with double distilled water before use and dried in an electric oven.

\section{Procedure}

$300 \mathrm{mg}$ of $\beta$-CDP and $2.5 \mathrm{~mL}$ of buffer solution ( $\mathrm{pH} 4.0$ ) were added to a $100 \mathrm{~mL}$ stoppered conical flask at room temperature. The mixture was allowed to stand for $5 \mathrm{~min} .3 \mathrm{~mL}$ of dye was added and made up to $90 \mathrm{~mL}$ with double distilled water. After the mixture was shaken in the thermostatic shaking water bath for $90 \mathrm{~min}$., $5.0 \mathrm{~mL}$ of supernatant solution was transferred into a $10 \mathrm{~mL}$ volumetric flask and the absorbance was measured using spectrophotometric method.

\section{Results and Discussion}

\section{Optimization of various parameters}

\section{Effect of $\mathrm{pH}$}

The complexation of the dye with the polymer depends on the $\mathrm{pH}$ of the sample solution which was studied in the range of (1.0-7.0.) using different buffer solutions. As it can be seen in Figure 1, \% uptake $(\geq 95)$ was obtained at $\mathrm{pH} 4.0$. Therefore, the working $\mathrm{pH}$ was chosen as 4.0 for the subsequent studies. 


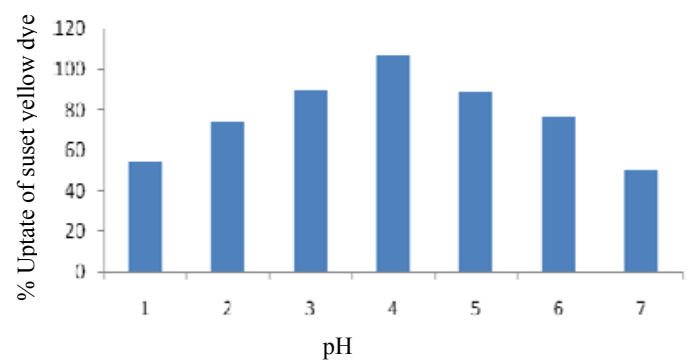

Figure 1. Effect of $\mathrm{pH}$ on the $\%$ uptake of the sunset yellow dye by the polymer

\section{Effect of shaking time}

Shaking time is an important factor in determining the possibility of application of the $\beta$-CD polymer for the selective uptake of sunset yellow dye. Different shaking time (ranging from 15 to $135 \mathrm{~min}$.) were studied for the \% uptake of sunset yellow dye by $\beta$-CD polymer. The results of $\%$ uptake of sunset yellow dye $v$ s. the shaking time show that the \% uptake of $(\geq 95 \%$ ) was attained at $90 \mathrm{~min}$ (Figure 2). Therefore, the shaking time of $90 \mathrm{~min}$. was selected for further studies.

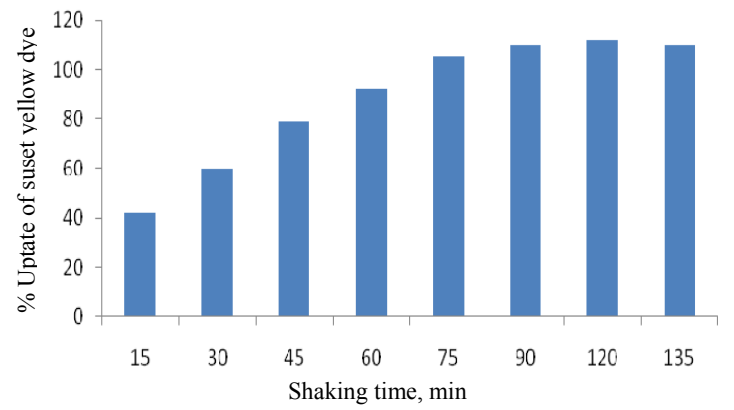

Figure 2. Effect of shaking time on the \% uptake of the sunset yellow dye by the polymer

\section{Effect of sample volume}

Sample volume is an important factor in determining the possibility of application of polymer for the $\%$ of uptake of sunset yellow dye. For this purpose 15, 30, 45, 60, 90 and $105 \mathrm{~mL}$ of sample volumes were taken and uptake of sunset yellow dye was studied (Figure 3). The maximum \% uptake ( $\geq 95 \%)$ of sunset yellow dye at sample volume of $90 \mathrm{~mL}$. Therefore, $90 \mathrm{~mL}$ of sample volume was used for the further studies.

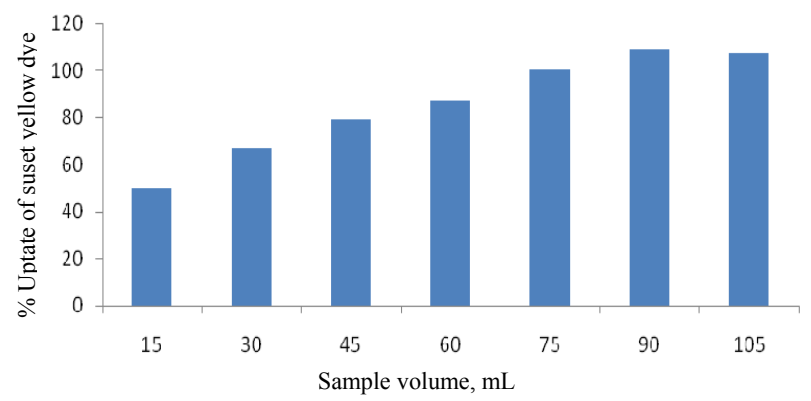

Figure 3. Effect of sample volume on the \% uptake of the sunset yellow dye by the polymer 


\section{Effect of agitation speed}

Speed of shaking is the important factor in determining the possibility of application of polymer for the quantitative \% uptake of sunset yellow dye. Different speed (ranging from 40 to 140 r.p.m.) were studied for the $\%$ uptake of sunset yellow dye by polymer. The results of $\%$ uptake of sunset yellow $v s$. agitation speed (Figure 4 ) shows that the $\%$ uptake reach maximum $(\geq 95 \%)$ at 140 r.p.m. Therefore, the shaking speed of 140 r.p.m. was selected for the further studies.

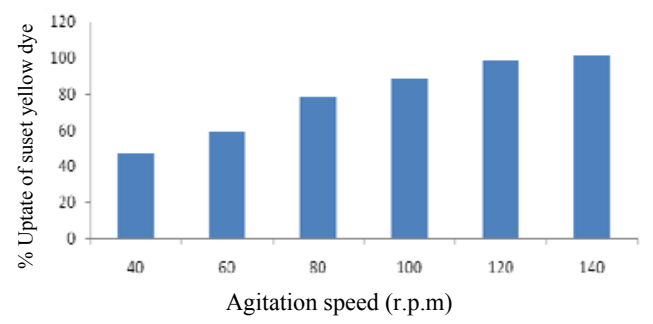

Figure 4. Effect of agitation speed on the \% uptake of the sunset yellow dye by the polymer

\section{Effect of amount of polymer}

The amount of the $\beta$-CD polymer is another important parameter that affects $\%$ uptake of dye. A quantitative removal $(\geq 95 \%)$ cannot be achieved when the $\beta$-CD polymer is less than the optimum amount. In order to optimize the smallest amount of polymer, 100, 200, 300, 400,500 and $600 \mathrm{mg}$ of the polymer were added to the solution containing known amount of dye. The quantitative recoveries were obtained at $300 \mathrm{mg}$ of $\beta$-CD shown in (Figure 5). Therefore, $300 \mathrm{mg}$ of the $\beta$-CD has been used for further studies.

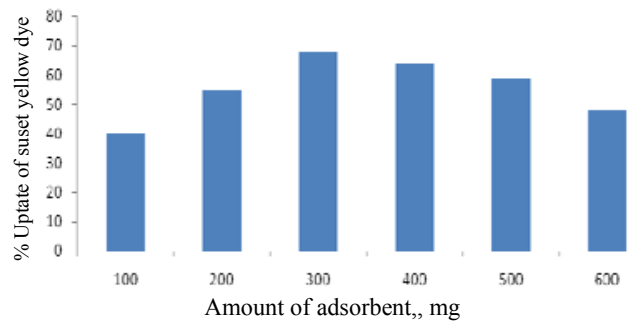

Figure 5. Effect of amount of adsorbent on the \% uptake of the sunset yellow by the polymer

\section{Applications}

\section{Determination of samples}

The proposed method has been applied for the determination of sunset yellow dye in Santra goli and Mirinda. The results are given in Table 1.

Table 1. Result of determination of sunset yellow in food samples

\begin{tabular}{cccc}
\hline Food samples & Added, ug/mL & Found, ug/mL & Recovery, \% \\
\hline${ }^{\mathrm{a}}$ Santra Goli & 0 & 0.020 & - \\
& $0.502 \mathrm{ug} / \mathrm{mL}$ & $0.487 \mathrm{Ug} / \mathrm{Ml}$ & $97.011 \%$ \\
& $1.005 \mathrm{ug} / \mathrm{mL}$ & $1.01 \mathrm{ug} / \mathrm{mL}$ & $100.49 \%$ \\
${ }^{\mathrm{b}}$ Mirinda & 0 & 0.022 & - \\
& $0.502 \mathrm{ug} / \mathrm{mL}$ & $0.489 \mathrm{ug} / \mathrm{mL}$ & $97.41 \%$ \\
& $1.005 \mathrm{ug} / \mathrm{mL}$ & $0.993 \mathrm{ug} / \mathrm{mL}$ & $98.80 \%$ \\
\hline
\end{tabular}

${ }^{a}$ Santra goli - locally available in market, ${ }^{b}$ Mirinda - locally available in market 


\section{Conclusion}

The proposed preconcentration method consist of a simple and low cost procedure which permits the quantitative recovery of sunset yellow dye from food samples. The synthesis of the polymer is easy and the method has a good accuracy, sensitivity and repeatability. The polymer has been used in all the experiments performed for the study. It has a unique stability and reusability. This method is convenient for the determination of sunset yellow dye.

\section{References}

1. Alves S P, Mares Brum D, Branco de Andrade E C and Netto A D P, Food Chem., 2008, 107(1), 489-496; http://dx.doi.org/10.1016/j.foodchem.2007.07.054

2. Llamas N E, Garrido M, Di Nezio M S and Fernandez B S B, Anal Chim Acta, 2009, 655(1-2), 38-42; http://dx.doi.org/10.1016/j.aca.2009.10.001

3. Ghorpade V M, Deshpande S S, Salunkhe D K, Maga J A and Tu A T (Eds), Food Additive Toxicology, Marcel Dekker, New York, 1995.

4. Coelho T M, Vidotti E C, Rollemberg M C, Medina A N, Baesso M L, Cella N and Bento A C, Talanta, 2010, 81(1-2), 202-207;

http://dx.doi.org/10.1016/j.talanta.2009.11.058

5. Farhadi K, Maleki R, Nezhad N M and Samadi N, Spectroscopy Lett., 2010, 43(2), 101-107; DOI:10.1080/00387010903278309

6. Ghaedi M, Shokrollahi A, Ekrampour F and Aghaei R, Bull Chem Soc Ethiop., 2009, 23, 337-345.

7. Ghaedi M, Amiradad S Z, Marahel F, Nasiri Kokhdan S, Sahraei R and Nosrati M, Daneshfar A, Spectrochimica Act Part A:Molecular Biomolecular Spectroscopy, 2011, 83(1), 46-51; http://dx.doi.org/10.1016/j.saa.2011.07.018

8. Yunus Emre Unsal, Mustafa Soylak and Mustafa Tuzen, Int J Food Sci Techol., 2012, 47(6), 1253-1258; DOI:10.1111/j.1365-2621.2012.02966.x

9. Bozodogan A, Ustun Ozgur M and Koyuncu I, Anal lett., 2000, 33(14), 2975-2982; DOI:10.1080/00032710008543235

10. Maria Madalina Jurcovan, Nicole Livia Atudosiei, Daniela Mihaila, Bulletin UASVM Agriculture, 2012, 69(2).

11. Snezana S Mitic, Ruzica J Micic and Ranko M Simonovic, Food Chem., 2009, 117(3), 461-465; http://dx.doi.org/10.1016/j.foodchem.2009.04.042

12. Mahmure Ustun Ozgur and Ikbal Koyuncu, Turk J Chem., 2002, 26(4), 501-508.

13. Marisol Gomez, Veronica Arancibia, Carlos Rojas and Edgar Nagles, Int $J$ Electrochem Sci., 2012, 7, 7493-7502.

14. Liu J, Wu B and Zhang B, J Chin Chem Soc., 2005, 52(6), 1165-1170;

DOI: $10.1002 /$ jecs.200500167

15. Li R, Jiang Z T and Liu Y H, J Food Drug Anal., 2008, 16, 91-96.

16. Velic D, Knapp M and Kohler G, J Mole Struct., 2001, 598(1), 49-56; http://dx.doi.org/10.1016/S0022-2860(01)00804-3

17. Abay I, Denizli A, Biskin E and Salih B, Chemosphere, 2005, 61(9), 1263-1272; http://dx.doi.org/10.1016/j.chemosphere.2005.03.079

18. Shao D, Sheng G, Chen C, Wang X and Nagastu M, Chemosphere, 2010, 79(7), 679685; http://dx.doi.org/10.1016/j.chemosphere.2010.03.008

19. Wu M and Zhu X, Spectrochim Acta A Mol Biomol Spectrosc., 2010, 77(5), 1021-1024; http://dx.doi.org/10.1016/j.saa.2010.08.061

20. Bhaskar M, Aruna P, Radhakrishnan G, Anal Chim Acta, 2004, 509(1), 39-45; http://dx.doi.org/10.1016/j.aca.2003.12.015 